\title{
Leadership behavior of deans as a determinant of faculty job satisfaction and job commitment
}

\author{
Naressia Seludo Ballena* \\ College of Nursing, University of the Philippines, Manila, Philippines
}

Received: August 7, 2021

DOI: $10.5430 /$ jnep.v12n3p58
Accepted: October 7, 2021

Online Published: November 9, 2021

\begin{abstract}
Background: Faculty job satisfaction and commitment contribute to the success of academic programs of a college. The main purpose of the study was to determine the relationship of leadership behavior of the deans of nursing colleges to the job satisfaction and job commitment of the faculty members.

Methods: The study used a descriptive correlational design. Twenty deans and 100 faculty members from 20 nursing colleges in the National Capital Region, Philippines participated. Survey instruments used were the (1) modified Leader Behavior Description Questionnaire, (2) modified Minnesota Job Satisfaction Questionnaire, and (3) Job Commitment Questionnaire. Leadership behavior was measured based on the "initiating structure" and "consideration" dimensions.

Results: Deans of nursing schools viewed their leadership behavior as "highly initiating" (M=44.0, SD = 5.61) and "very highly considerate" $(M=50.1, S D=4.99)$. Assessment of faculty members revealed congruent findings for the leadership dimensions of initiating structure $(\mathrm{M}=46.6, \mathrm{SD}=3.83)$ and consideration $(\mathrm{M}=49.9, \mathrm{SD}=2.66)$. Faculty members were generally "satisfied" $(\mathrm{M}=4.20, \mathrm{SD}=.25)$ and "committed" $(\mathrm{M}=4.00, \mathrm{SD}=.23)$ to their teaching job. Among the recently established colleges, the "initiating structure" dimension was highly positively correlated with job commitment of faculty members, $\mathrm{r}=.82, p<.05$. There were no statistically significant relationships between the school classification, and the job satisfaction and job commitment of nursing faculty members.

Conclusions: Measures must be instituted to improve the "initiating structure" behavior of deans of recently established nursing schools to increase job commitment of faculty members. Other factors associated with job satisfaction and job commitment should be explored.
\end{abstract}

Key Words: Leadership behavior, Job satisfaction, Job commitment

\section{INTRODUCTION}

The successful operation of a college of nursing depends on the competence of the nurse administrator - the Dean. A Deanship position is described both as a seat of leadership and administration. As a leader, it is essential to establish and implement the vision and direction of the school and take responsibility for the success of the college. As administrator and manager, the dean is responsible for fac- ulty member selection and development, curriculum development and programming, financial management, student and program evaluation, public relations, and planning. The dean performs many functions such as organizing, planning, decision-making. It also includes budgeting, creating and revising policies and meetings with college and university affiliates. ${ }^{[1]}$

The Commission on Higher Education (CHED) has several

\footnotetext{
*Correspondence: Naressia Seludo Ballena; Email: nsballena@up.edu.ph; Address: College of Nursing, University of the Philippines, Manila, Philippines.
} 
requirements for the proper selection of Deans of Colleges of Nursing. These include the following criteria: (1) full-time in her/his position, (2) a registered nurse, (3) with clinical experience, and (4) with at least five years of experience in teaching, administrative and supervisory positions. ${ }^{[2,3]}$

From 2000 to 2006, nursing was observed to be one of the most in demand college programs in the country that resulted to rapid increase in the establishment of nursing schools. The mushrooming of nursing schools resulted in an increase in the need for qualified nurse administrators for the position of dean, and nurse educators for the teaching position. Moreover, the rapid bloom of nursing colleges resulted in decreasing quality of nursing education which was evidenced by the plummeting of Nurse Licensure Examination (NLE) passing rates from 1998 to 2008. ${ }^{[4]}$

\subsection{Leadership}

Leadership is defined as "the process of influencing others to achieve mutually agreed upon purposes for the organization." First, leadership is a process; it is not a personal trait or characteristic of an individual. Second, leadership involves influence; it requires interactions and relationships among people. Third, leadership involves purpose; it helps organizations and the people affiliated with them. This definition of leadership highlights the fact that leadership can be shared amongst multiple actors and relies on complex, organic interrelationships between leaders, helpers, and followers. ${ }^{[5]}$

The two basic leadership styles deal with whether a leader focuses on the task at hand or the welfare and satisfaction of the people doing it. The leader's emphasis may either be on production or on people. Some leadership researchers have focused on the personality, physical traits, or behaviors of the leader. Others have studied how aspects of the situation affect the ways leaders act. Some have extended the latter viewpoint so far as to suggest there is no such thing as leadership; they argue that organizational success and failures often get falsely attributed to the leader, but the situation may have a much greater impact on how the organization functions that does any individual, including the leader. ${ }^{[6]}$

\subsection{Leadership behavior approaches}

The behavior approach says that anyone who adopts the appropriate behavior can be a good leader. Diverse research programs on leadership behavior have sought to uncover the behaviors that leaders engage in rather than what traits a leader possesses. Behaviors can be learned more readily than traits, enabling leadership to be accessible to all. ${ }^{[7]}$ One advantage of assessing leaders in terms of behavior is that it is often easier to measure. Leadership behaviors can be observed whereas personality traits, values, or intelligence

Published by Sciedu Press must be inferred from behavior or measured with tests. Moreover, many people are less defensive about, and feel in more control of, specific behaviors than they do about their personalities or intelligence. ${ }^{[8]}$

The Ohio State Model of Leadership Behavior, one of the theoretical bases of this study, was developed based on a study on leadership initiated in 1945 by the Bureau of Business Research at the Ohio University to identify various dimensions of leader behavior. The two dimensions are (1) initiating structure and (2) consideration. Initiating structure is the extent to which a leader is likely to organize and define relationships between himself and his co-workers in terms of the roles which he expects each member to assume, endeavoring to establish well-defined patterns of the organizations, channels of communication and ways of getting the job done. ${ }^{[8,9]}$ In contrast, consideration is the extent to which a leader is likely to maintain personal relationships between himself and the members of the group in terms of socio-emotional support characterized by friendship, mutual trust and respect for co-worker's ideas. ${ }^{[9]}$

Alejandro ${ }^{[9]}$ explained that these dimensions are the two major and interrelated concerns of any administrator. The initiating structure dimension is concern for the task while the consideration dimension is concern for people. Thus, administrators may be classified according to how they rate in each of these two dimensions.

Considerate leaders are also known as expressive leaders because they show concern for people. They have been found to facilitate a group with higher productivity and higher performance. ${ }^{[10]}$ In addition, leadership consideration is more conducive to job satisfaction. ${ }^{[10,11]}$ On the other hand, taskstructure leaders, also known as instrumental leaders, show less concern for employees and are high on initiating structure. According to Robbins ${ }^{[13]}$ leader behavior characterized as high on initiating structure led to greater rates of grievances, absenteeism, and turnover and lower levels of job satisfaction for workers performing routine tasks.

The researchers at the University of Michigan sought to identify leader behaviors that contributed to effective group performance. ${ }^{[6]}$ The study classified leaders' behaviors as being job-centered dimensions and employee-centered dimensions. A leader is identifiable by the behavior characteristic of one or the other style, but not both. Another hallmark of later Michigan studies is the acknowledgment that often the behaviors of goal emphasis, work facilitation, support, and interaction facilitation can be meaningfully performed by a subordinate's peers, rather than only the designated leader. ${ }^{[7]}$ The studies conducted by Ohio State and University of Michigan were a substantial step in describing the leaders actually 
do.

Blake and Mouton ${ }^{[14]}$ proposed a two-dimensional leadership theory called "The Leadership Grid" that builds on the work of the Ohio State and Michigan studies. The Grid implies that the most effective leadership is characterized by the combination of high concern for production with high concern for people. ${ }^{[6]}$ Another conceptualization of leadership behavior that contributed to the study is the Hersey-Blanchard Situational Leadership theory. It is based on the amount of direction (task behavior) and amount of socio-emotional support (relationship behavior) a leader must provide given the situation and the "level of maturity" of the followers. ${ }^{[15]}$

A study conducted by Leary and group ${ }^{[16]}$ suggested that there was a relationship between leadership styles and faculty job satisfaction. The results of this study indicated that there is a significant relationship between leadership styles of the dean and the self-reported job satisfaction of faculty members. Generally, overall job satisfaction scores increased as one or the other dimensions of leadership behaviors were attributed to deans or department chairs. There was a weak relationship between the initiating structure of the LBDQ and intrinsic job satisfaction. The consideration dimension of the LBDQ was also weakly correlated with reported intrinsic job satisfaction scores. Neither dimension of leadership behavior contributed to an increase in intrinsic job satisfaction. ${ }^{[16]}$

Bright and Richards ${ }^{[17]}$ described the most common path to deanship as the "accidental tourist," that is, leaders start off as faculty, then advance to administrative roles or faculty management positions, before achieving deanship. Academic leaders are frequently selected based only on academic achievements, rather than experience in leadership. Thus, ensuring that deans execute leadership approaches efficiently is an organizational responsibility.

\subsection{Job satisfaction}

As defined in this study, job satisfaction consists of a variety of factors involving the faculty member's feelings toward leadership behavior of the deans and the work environment. It also involves a wide range of attitudes about their work and work-related issues. Each of these attitudes contains cognitive, affective and psychomotor components. ${ }^{[18]}$

The concept of job satisfaction is based on a theoretical framework in the realm of work motivation. The maintenance of work-related behaviors implies that the conditions of the job somehow provide for the needs of the individual, fostering a sense of satisfaction. Workers at every level form impression regarding whether they are valued and respected from important cues that emanate from their environment, especially those that come from the leaders directly above them. ${ }^{[19]}$

The variables of job satisfaction are helpful in explaining job performance variance among different groups. Primary variables include age, years on the job, occupation field, organizational level, educational attainment, and gender. ${ }^{[19]}$

In terms of Herzberg's motivation-hygiene theory, ${ }^{[20]}$ factors that make employees feel good about their work, are different from factors that make them feel bad about their work. Factors that play a role in contributing to the satisfaction of employees are called motivators, while hygiene factors contribute to job dissatisfaction. These two factors are also called the intrinsic (internal) and extrinsic (external) factors.

Intrinsic factors (e.g., opportunities for advancement and growth, recognition, responsibility, achievement) promote job satisfaction, whereas extrinsic factors (e.g., supervision, pay, policies, working conditions, interpersonal relations, security) prevent job dissatisfaction. In order to prevent job dissatisfaction and retain employees in their current jobs, employers need to keep up with changing values related toward work. $^{[21]}$

\subsection{Job commitment}

Commitment is based on the degree of congruence among personal, professional, and organizational or employer goals and purposes. However, there are stronger emotions, involved in the case of organizational commitment and it is manifested by the affinity of the employee to the organization and readiness to make sacrifices for the company. Morale is a key factor in determining an employee's commitment to work and the degree of job satisfaction to which he or she professes. ${ }^{[22]}$ Benton ${ }^{[23]}$ defined commitment as an attachment to an organization that allows people to do things on their own willingly. He stressed that people need commitment for themselves and their organization and further explained that commitment is the keystone of renewed productivity and profitability in many organizations.

\subsection{Research questions}

The study sought to determine the leadership behavior of deans of selected colleges of nursing in the National Capital Region (NCR), Philippines and measure its association with job satisfaction and job commitment of nursing faculty members. The end goal of the study was to identify its implications to nursing school administration.

Specifically, it answered the following research questions:

1) What is the leadership behavior of deans of nursing colleges as perceived by the deans themselves and faculty members in the dimensions of: 
- initiating structure, and

- consideration?

2) Does the leadership behavior of deans of nursing colleges, in terms of initiating structure and consideration dimension, significantly differ when compared according to school classification (whether recently established or established)?

3) What is the level of job satisfaction of faculty members of nursing colleges in NCR?

4) Is there a significant difference on job satisfaction of faculty members of nursing colleges in NCR with school classification?

5) What is the level of job commitment of faculty members of nursing colleges in NCR?

6) Is there a significant difference on job commitment of faculty members of nursing colleges in NCR with school classification?

7) Do job satisfaction and job commitment of faculty members of nursing colleges in NCR significantly differ with leadership behavior of nursing deans?

8) Do job satisfaction and job commitment of faculty members of nursing colleges in NCR, as determined by leadership behavior of nursing deans, significantly differ when tested simultaneously?

\subsection{Theoretical framework}

The leadership theory tested in this study was based on the Halpin's Initiating Structure and Consideration Theory of Leadership. ${ }^{[8]}$ The two dimensions are initiating structure and consideration. Ohio leadership studies described this as people-oriented (consideration) and task-oriented (initiat- ing structure) aspects, to facilitate goal accomplishment. ${ }^{[24]}$ On the other hand, Michigan leadership studies described the dimensions as being production-centered or employeecentered. $^{[25]}$

The researcher utilized the theories reviewed in the study. It gave framework to the two dimensions of leader behavior used in the study. The key assumptions underlying in the theories was that certain behaviors could be universally associated with a leader's ability to successfully influence a group toward the accomplishment of its goals as well as productivity and satisfaction of subordinates. Although the theoretical approach used in the study might not necessarily reflect contemporary views, this was chosen by the researcher in order to categorically highlight the differences between task-oriented and people-oriented leadership behaviors of deans.

\subsection{Conceptual framework}

Figure 1 illustrates the study variables and the relationships that the research study investigated. These are the leadership behavior of deans in terms of "initiating structure" and "consideration dimension," and the level of job satisfaction and job commitment of nursing faculty members.

This study examined the associations among job commitment, job satisfaction, school classification. Moreover, it also determined the influence of leadership behavior of deans to faculty job satisfaction and faculty job commitment. Lastly, the results of the study were utilized to determine the possible implications to nursing school administration.

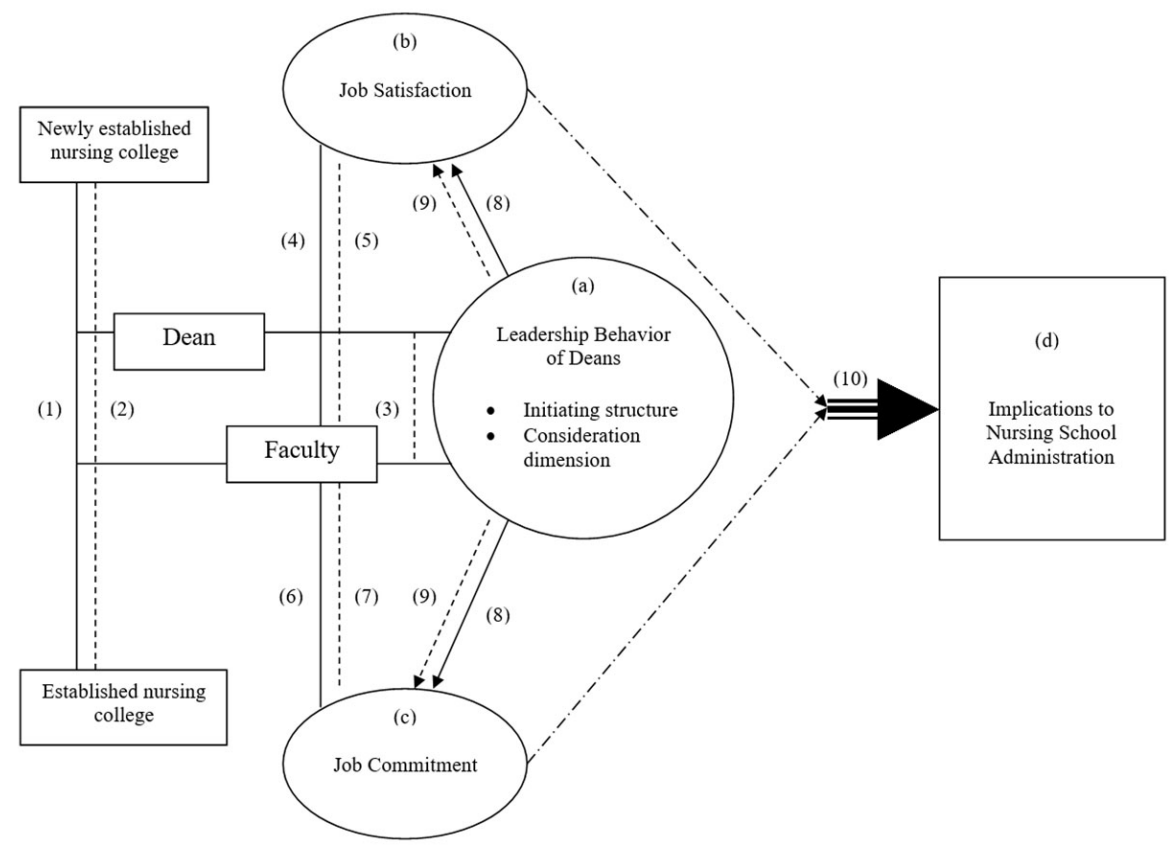

Figure 1. Conceptual model of leadership behavior, job satisfaction, and job commitment 


\section{MethodS}

\subsection{Research design, population and sample}

Since the study aimed to describe and correlate the leadership behavior of deans, and the job satisfaction and job commitment levels of faculty members, the descriptive correlational research design was deemed most applicable. ${ }^{[26]}$ The respondents for the study were purposively selected. The inclusion criteria for the deans were: (1) s/he must be in the position for more than a year and (2) s/he is an eligible member of the Association of Deans of Philippine Colleges of Nursing (ADPCN). On the other hand, the faculty members were (1) full-time in status and (2) affiliated with the school for more than a year. The final sample was twenty (20) deans and one hundred (100) faculty members from 20 colleges of nursing in National Capital Region, Philippines. The number of faculty respondents was patterned on the manual of LDBQ[26] with a minimum requirement of four (4) to a maximum of seven (7) respondents per nursing college.

\subsection{Variables and instrumentation}

\subsubsection{Leadership behavior of deans}

The data gathering instrument for the independent variable (leadership behavior) is the modified Leader Behavior Description Questionnaire (LBDQ) originally developed by Andrew W. Halpin. ${ }^{[27]}$ The LBDQ is a 30-item instrument which describes how a leader behaves. The two aspects of leadership behavior measured were the consideration and initiating structure dimensions.

Based on the Manual for the LBDQ of Ohio State University, the respondents indicated the frequency with which they perceived the leader to engage in each type of behavior by marking one of items in the 5-point Likert scale: (1) never, (2) seldom, (3) occasionally, (4) often, and (5) always. ${ }^{[27]}$ The most negative statement is scored 1; the most positive statement is scored 5, and all responses are scored between 1 and 5. Higher scores indicated more favorable leadership behaviors, while the lower scores indicated less favorable leadership behaviors.

Since the leadership behavior of deans is the interest of the study, the items in the LBDQ were modified based on the study variables. Two versions of the questionnaire were created for the respective uses of the dean and faculty members. The modified LBDQ was validated by the nursing deans who were not included as respondents of the study. Cronbach $\alpha$ for "initiating structure" was 0.91 while the "consideration" dimension was at 0.73 . The results indicate that the questionnaire items were statistically reliable.

\subsubsection{Faculty job satisfaction}

To measure the first dependent variable, job satisfaction, the modified Minnesota Job Satisfaction Questionnaire was utilized based on the work of Weiss and team ${ }^{[28]}$ on the Minnesota Satisfaction Questionnaire (MSQ). The tool was used to determine the faculty satisfaction with their job. This 20item self-administered instrument conceptualizes job satisfaction as being related to either intrinsic or extrinsic aspects of the job. It takes 5 to 10 minutes to complete the questionnaire. The Cronbach $\alpha$ was .90 which indicates high internal consistency.

The respondents provided responses through a 5-point Likert scale: (1) least satisfied, (2) less satisfied, (3) moderately satisfied, (4) satisfied, and (5) very satisfied. The most negative statement is scored 1 ; the most positive statement is scored 5 , and all responses are scored between 1 and 5. Higher scores indicated higher job satisfaction, while the lower scores indicated lesser perceived job satisfaction.

\subsubsection{Faculty job commitment}

To measure the second dependent variable, job commitment, the 17-item Job Commitment Questionnaire was used to determine the job commitment level of the faculty. The Cronbach $\alpha$ was high, ranging from .82 to .93 , with a median of .90. The respondents provided responses through a 5-point Likert scale: (1) least committed, (2) less committed, (3) moderately committed, (4) committed, and (5) very committed. The most negative statement is scored 1; the most positive statement is scored 5 , and all responses are scored between 1 and 5 . Higher scores indicated higher job commitment, while the lower scores indicated lesser perceived job commitment.

The modified Minnesota Job Satisfaction Questionnaire and Job Commitment Questionnaire were validated by a Guidance Counselor and a Director of Human Resource Management. The Guidance Counselor's expertise was considered because several items in the questionnaires pertain to behaviors. Before data collection, the instruments were pilot tested to 20 faculty members who were not included as part of the sample. The responses were statistically processed to determine the reliability of each item.

\subsubsection{School classification}

The school classification variable was categorized as (1) recently established and (2) established nursing schools. A school of nursing is considered recently established if it started in year 2002 onwards, while an established school of nursing have been operational since before the year 2002 . 


\subsection{Procedure for gathering data}

The researcher obtained ethics approval from the Ethics Review Board of Trinity University of Asia. Upon approval, the researcher discussed to the Deans of Colleges of Nursing and their faculty the purpose of the study.

The researcher provided the questionnaires to the deans and faculty members and collected them on the same day or within the next 2-3 days. The information regarding the context of the study was placed on the first page, together with the informed consent form which needed to be understood and signed before proceeding to the questionnaire. The participants were asked to fill out the forms. The questionnaires did not ask for any identifiers of personal information such as name and birthday to ensure the anonymity of participants and minimize bias in data analysis. Moreover, the researcher required the participants to submit their responses in a sealed drop box located in the office of the nursing faculty to further strengthen anonymity and confidentiality. Deans and faculty members who did not consent to participate or withdrew participation from the study were allowed to do so without any consequences. A period of one month was allotted by the researcher for data gathering.

\subsection{Data analysis}

The researcher secured the collected data set and encoded it

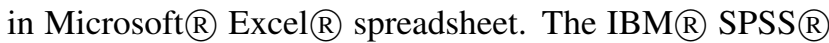
Statistics v16.0 (Statistical Package for the Social Sciences) software was used for statistical analysis. To describe the leadership behavior of deans, the score for each dimension is the sum of scores assigned to responses marked on 15 items in each of the two leadership dimensions. The possible range of scores on each dimension is 0 to 60 . The total numerical scores were interpreted using the following guide shown in Table 1:

Table 1. Scoring and Interpretation Guide for the LBDQ responses

\begin{tabular}{ll}
\hline Numerical score & Adjectival Rating \\
\hline $49-60$ & Very highly initiating/Very highly considerate \\
$37-48$ & Highly initiating/Highly considerate \\
$25-36$ & Moderately initiating/Moderately considerate \\
$13-24$ & Less initiating/Less considerate \\
$1-12$ & Least initiating/Least considerate \\
\hline
\end{tabular}

To describe job satisfaction and job commitment of faculty members, the weighted mean for each statement was computed. Thereafter, the overall weighted mean was computed and interpreted using the following scale shown in Table 2:

To test the difference in the leadership behaviors of deans, job satisfaction of faculty members, and job commitment level

Published by Sciedu Press of faculty members when grouped by school classification, the independent $t$-test was used.

Table 2. Scoring and Interpretation Guide for the Job Satisfaction and Job Commitment ratings

\begin{tabular}{ll}
\hline Numerical score & Adjectival Rating \\
\hline $4.21-5.00$ & Very satisfied/Very Committed \\
$3.41-4.20$ & Satisfied/Committed \\
$2.61-3.40$ & Moderately satisfied/Moderately committed \\
$1.81-2.00$ & Less satisfied/Less committed \\
$1.00-1.80$ & Least satisfied/Least committed \\
\hline
\end{tabular}

Regression analysis was used to test whether initiating structure and consideration determine job satisfaction and job commitment levels of faculty members when accounted for simultaneously. In particular, the multiple regression (R) measured the correlation of the variables, while the adjusted $\mathrm{R}^{2}$ determined by how much leadership behaviors influence job satisfaction level and job commitment of faculty members.

To determine which among the two test variables were significantly determined by leadership behavior when classified into initiating structure and consideration dimensions, the beta-coefficients were measured and analyzed. The standardized beta was used to compare the influence of leadership behavior when it is broken down into "initiating structure" and "consideration". On the other hand, the amount of influence of each leadership behavior was measured by the unstandardized beta-coefficients. To test the significance of the regression model, the F-test was used.

The decision to accept or reject the null hypothesis was based on the computed p-value. The significance level was set at $p<.05$. Thus, if the computed $\mathrm{p}$-value is greater than 0.05 , the regression model is deemed not significant while if it is less than .05 , the regression model is considered statistically significant.

To test whether initiating structure and consideration as dimensions of leadership behavior correlate with job satisfaction and job commitment of faculty members differently, the multivariate analysis of variance (MANOVA) test was utilized. Specifically, the Wilk's lambda $(\Lambda)$ was determined and analyzed. The $\mathrm{F}$ values were evaluated against critical values of $\mathrm{F}$.

\section{Results}

\subsection{Leadership behavior of deans}

Initiating structure dimension was highly exhibited by the deans of selected nursing colleges in NCR. Among the total of 20 deans, the mean score ( \pm SD) in the LBDQ scale was 
44.0 ( $\mathrm{SD}=5.6$ ), which was interpreted as "highly initiating." Among the deans from recently established nursing colleges, the mean score was 45.3 ( $\mathrm{SD}=6.0$ ), interpreted as "highly initiating." Meanwhile, among the deans from established nursing colleges, the mean score was $43.4(\mathrm{SD}=5.4)$, which was also interpreted as "highly initiating."

Among the LBDQ items under "initiating structure", the following item was given the highest average score of 3.6 $(\mathrm{SD}=$ .69) by deans: Item 13: Letting faculty members know what is expected of them. On the other hand, Item 5: Speaking in a manner not to be questioned, obtained the lowest mean score of $1.2(\mathrm{SD}=1.06)$.

In general, the 100 faculty members viewed the deans as "highly initiating," with the overall mean score of 46.6 (SD = 3.83). Among the faculty members from recently established nursing colleges, the mean score was 46.7 ( $\mathrm{SD}=3.08$ ), interpreted as "highly initiating." Meanwhile, among the faculty members from established nursing colleges, the mean score was $46.5(\mathrm{SD}=4.22)$, which was also interpreted as "highly initiating."

Notable initiating structure behavior observed with mean score of $3.83(\mathrm{SD}=0.41)$ was Item 3: Ruling with an iron hand. Initiating behavior less observed by faculty members on their dean with the lowest mean score of $1.17(\mathrm{SD}=.98)$ was Item 5: Speaking in a manner not to be questioned by faculty members.

The 20 deans considered themselves as "very highly considerate" which was indicated by the overall mean score of $50.15(\mathrm{SD}=4.99)$ based on their self-assessment rating. Among the deans from recently established nursing colleges, the mean score was 50.83 ( $\mathrm{SD}=3.07)$, interpreted as "very highly considerate." Meanwhile, among the deans from established nursing colleges, the mean score was 49.9 ( $\mathrm{SD}=5.70$ ), which was also interpreted as "very highly considerate."

Specifically, results of their self-evaluation rating showed that they look out for the personal welfare of individual faculty members. The following scale items obtained mean score of $3.80(\mathrm{SD}=.41)$ : Item 13 : They make faculty members feel at ease when talking with them, and Item 15: They get the approval of faculty members on important matters before acting.

The faculty assessment of the leadership behavior of their respective deans in terms of consideration dimension is indicative that nursing college deans are "very highly considerate," with the overall mean score of $49.9(\mathrm{SD}=2.66)$. Among the faculty members from recently established nursing colleges, the mean score was 51 ( $\mathrm{SD}=2.82)$, interpreted as "very highly considerate." Meanwhile, among the faculty mem- bers from established nursing colleges, the mean score was $49.3(\mathrm{SD}=2.53)$, which was also interpreted as "very highly considerate."

The consideration behavior with the highest mean score of $3.85(\mathrm{SD}=.37)$ include: Item 11: Willingness to make changes in the college they are administering. Meanwhile the item that received the lowest mean score of 2.25 ( $\mathrm{SD}=$ $.85)$ was Item 3: Being easy to understand.

\subsection{Job satisfaction}

The overall satisfaction mean rating of faculty members was 4.17 ( $\mathrm{SD}=.29$ ), which was interpreted as "satisfied." Among the items pertaining in the modified Minnesota Job Satisfaction Questionnaire, the faculty members gave the highest mean score of $4.44(\mathrm{SD}=.37)$, which was interpreted as "very satisfied," to Item 9: "The chance to do things for other people within and outside of the College/University." However, the item that received the lowest satisfaction score was Item 12: "The way the College/University policies are put into practice," with mean score of 3.70 (SD = .47). The mean level of satisfaction ranges from a low of 3.90 to a high of 4.66 across the samples. Mean scores were typically above the midpoint on the 5-point Likert scale. Additionally, standard deviations indicate an acceptable distribution of participant responses.

Among the recently established nursing colleges, the job satisfaction mean rating of faculty members was 4.20 (SD $=.25$ ), which was also interpreted as "satisfied." The item that had the highest mean score of $4.45(\mathrm{SD}=.23)$, and the highest level of job satisfaction, was Item 11: "The chance to do things that makes use of my abilities." On the other hand, the item with the lowest mean satisfaction score of 3.80 $(\mathrm{SD}=.45)$ was Item 12: "The way the College/University policies are put into practice."

As to the faculty members from established nursing colleges, the item that had the highest mean score of $4.47(\mathrm{SD}=.41)$ was Item 9: "The chance to do things for other people within and outside of the College/University." The item with the lowest satisfaction rating was Item 12: "The way the College/University policies are put into practice," with a mean score of 3.66 ( $\mathrm{SD}=.49$ ). In general, faculty members from established colleges were "satisfied" with their job $(M=4.16$, $\mathrm{SD}=.31)$.

\subsection{Job commitment}

Generally, the scores of faculty members indicated that they are "committed" to their teaching job having obtained an overall mean rating of 3.99 ( $\mathrm{SD}=.23$ ). Among the items in the modified Job Commitment Questionnaire, the faculty members gave the highest mean score of $4.76(\mathrm{SD}=.23)$, 
which was interpreted as "very committed," to Item 3: "Being loyal to teaching job." However, the item that received the lowest job commitment score was Item 15: "Feeling like going to school for work than staying at home," with mean score of 2.79 ( $\mathrm{SD}=1.04)$. The mean level of job commitment ranges from a low of 3.59 to a high of 4.46 across the samples. Mean scores were usually above the middle of the 5-point Likert scale. Additionally, standard deviations indicate an acceptable distribution of participant responses.

Among the recently established nursing colleges, the job commitment mean score was $3.97(\mathrm{SD}=.30)$, which was interpreted as "committed." The item that had the highest mean score of 4.77 ( $\mathrm{SD}=.20)$, and the highest level of job commitment, was Item 3: "Being loyal to teaching job." On the other hand, the item with the lowest mean commitment score of 2.77 ( $\mathrm{SD}=.56$ ) was Item 14: "Having my work as a teacher/professor more important than other activities."

As for the faculty members from established nursing colleges, the item that had the highest mean score of 4.76 (SD $=.25$ ) was Item 3: "Being loyal to teaching job." The item with the lowest commitment rating was Item 15: "Feeling like going to school for work than staying at home," with a mean score of $2.24(\mathrm{SD}=.61)$. In general, faculty members from established colleges were "committed" to their job (M $=4.01, \mathrm{SD}=.21)$.

\subsection{Relationship of leadership behavior of deans to job satisfaction and job commitment}

To test the hypothesis that leadership behavior of deans significantly determine job satisfaction and job commitment of nursing faculty members, several statistical tests were undertaken. The initial test was to determine the relationship between the variables using a bivariate test through a Pearson's correlation test. This was done to examine the degree of relationship between the variables.
According to Cohen, ${ }^{[29]}$ Pearson $r$ values are interpreted as:

- $0.1 \leq|\mathrm{r}| \leq .3$ - weak correlation

- $0.3<|\mathrm{r}| \leq .5$ - moderate correlation

- $0.5<|\mathrm{r}| \leq 1.0-$ strong correlation

Considering all participant colleges, the correlation analysis revealed that the relationships between the dimension of leadership behavior and job satisfaction and commitment were not statistically significant. The $p$-values were above the significance level of .05. The Pearson $r$ values among the variables were at the low correlation strengths.

Among the recently established colleges, the "initiating structure" dimension as leadership behavior of deans was highly positively correlated with the level of job commitment of faculty members, $\mathrm{r}=.82, p<.05$. The strong, direct relationship between these variables implied that as deans develop and manifest "initiating structure" as leadership behavior, the level of job commitment of faculty members from recently established schools tend to also increase. All other variables tested among recently established colleges were not significantly correlated. The Pearson $r$ values among the variables range from -.15 at the lowest and .82 at the highest.

Among the established colleges, correlation tests revealed that none of the tested variables were significantly related. The p-values were above the level of significance. The Pearson $r$ values among the variables were typically observed to be at weak to moderate correlations with the lowest at .033 and highest at .36. Thus, the null hypothesis is accepted. Leadership behavior of deans does not significantly determine job satisfaction and job commitment of nursing faculty members.

Table 3 presents the summary of computed Pearson $\mathrm{r}$ coefficients determining the significant relationship between leadership behavior of deans and job satisfaction and job commitment of faculty members.

Table 3. Summary of computed r-coefficients determining the significant relationship between leadership behavior of deans and job satisfaction and job commitment of faculty members

\begin{tabular}{|c|c|c|c|c|c|c|c|}
\hline \multirow{2}{*}{ Variable } & \multirow{2}{*}{$\begin{array}{l}\text { Test } \\
\text { Statistic }\end{array}$} & \multicolumn{2}{|c|}{ Recently Established Colleges } & \multicolumn{2}{|c|}{ Established Colleges } & \multicolumn{2}{|l|}{ All Colleges } \\
\hline & & Satisfaction & Commitment & Satisfaction & Commitment & Satisfaction & Commitment \\
\hline $\begin{array}{l}\text { Initiating } \\
\text { Structure }\end{array}$ & $\begin{array}{l}\text { Pearson } r \\
\text { ( } p \text {-value) }\end{array}$ & $\begin{array}{l}.28 \\
(p=.59)\end{array}$ & $\begin{array}{l}.82 * \\
(p=.044)\end{array}$ & $\begin{array}{l}.16 \\
(p=.59)\end{array}$ & $\begin{array}{l}-.15 \\
(p=.61)\end{array}$ & $\begin{array}{l}.18 \\
(p=.45)\end{array}$ & $\begin{array}{l}.23 \\
(p=.33)\end{array}$ \\
\hline Consideration & $\begin{array}{l}\text { Pearson } r \\
\text { ( } p \text {-value) }\end{array}$ & $\begin{array}{l}-.15 \\
(p=.77)\end{array}$ & $\begin{array}{l}.53 \\
(p=.28)\end{array}$ & $\begin{array}{l}.36 \\
(p=.20)\end{array}$ & $\begin{array}{l}.033 \\
(p=.91)\end{array}$ & $\begin{array}{l}.27 \\
(p=.25)\end{array}$ & $\begin{array}{l}.13 \\
(p=.60)\end{array}$ \\
\hline
\end{tabular}

${ }^{*}$ Correlation significant at .05 level (two-tailed). $r$. Correlation coefficient.

To test whether leadership behavior of deans predict job satisfaction and job commitment of faculty members, a regression analysis was performed.

Considering all participant colleges when "initiating struc- 
ture" and "consideration" dimensions were taken collectively, leadership behavior of deans do not significantly correlate with job satisfaction or job commitment levels of faculty members with $p$-values above the significance level. The computed regression equation coefficients $(\mathrm{R})$ were 0.285 and 0.234 , respectively.

For recently established schools, there is a high degree of variance in job satisfaction and job commitment of faculty members that could be attributed to the leadership behavior of deans in terms of "initiating structure" and "consideration" dimensions. Worth mentioning is the adjusted $\mathrm{R}^{2}$ results which indicate that $42.3 \%$ of the variance in job satisfaction of faculty members is due to "initiating structure" and "consideration" dimensions. For job commitment the variance is larger at $64.8 \%$. The variances, however, were not significant due to $p$-values above the .05 level.
In contrast, the regression outcome for the established nursing schools was rather negligible. For job satisfaction, the variance was $-1.70 \%$, while for job commitment, it was only $-15.00 \%$. These coefficients were, however, not significant with the $p$-values of .44 and .62 , respectively.

Therefore, the null hypothesis is accepted. Leadership behavior of deans does not predict job satisfaction and job commitment of faculty members.

Tables 4-6 present the summary of the computed regression coefficients measuring the influence of leadership behavior of deans of recently established and established nursing colleges on job satisfaction level and job commitment level of faculty members when tested collectively and autonomously. The correlation test was only utilized to explain the procedure for the regression analysis.

Table 4. Dimensions of leadership behavior, and job satisfaction and job commitment (collective tests)

\begin{tabular}{lccccc}
\hline Variable & $\boldsymbol{R}$ & $\boldsymbol{R}^{2}$ & Adjusted $\boldsymbol{R}^{2}$ & $\mathbf{F}$ & $\boldsymbol{p}$-value \\
\hline Recently Established Colleges & & & & \\
Satisfaction & .809 & .654 & .423 & 2.84 & .20 \\
Commitment & .888 & .789 & .648 & 5.60 & .097 \\
Established Colleges & & & & .891 & .44 \\
Satisfaction & .373 & .139 & -.017 & .154 & .62 \\
Commitment & .165 & .027 & -.150 & .750 & .49 \\
All Colleges & & & & .491 & .62 \\
Satisfaction & .285 & .081 & -.027 & -.057 & \\
Commitment & .234 & .055 & & & \\
\hline Note. Level of significance (two-tailed) $=.05$ & & & & \\
\hline
\end{tabular}

Note. Level of significance (two-tailed) $=.05$

Table 5. Dimensions of leadership behavior and job satisfaction (autonomous tests)

\begin{tabular}{|c|c|c|c|c|c|}
\hline \multirow{2}{*}{ Variable } & \multicolumn{2}{|c|}{ Unstandardized coefficients } & \multirow{2}{*}{$\begin{array}{l}\text { Standardized coefficients } \\
\text { Beta }(\beta)\end{array}$} & \multirow{2}{*}{$t$} & \multirow{2}{*}{$p$-value } \\
\hline & B & Std. error & & & \\
\hline \multicolumn{6}{|c|}{ Recently Established Colleges } \\
\hline (Constant) & 7.16 & 1.82 & & 3.93 & .029 \\
\hline Initiating Structure & .075 & .032 & 1.52 & 2.34 & .10 \\
\hline Consideration & -.128 & .057 & -1.45 & -2.23 & .11 \\
\hline \multicolumn{6}{|l|}{ Established Colleges } \\
\hline (Constant) & 3.02 & 1.02 & & 2.95 & .01 \\
\hline Initiating Structure & .006 & .019 & .085 & .30 & .77 \\
\hline Consideration & .018 & .015 & .346 & 1.21 & .25 \\
\hline \multicolumn{6}{|l|}{ All Colleges } \\
\hline (Constant) & 3.22 & .81 & & 4.0 & .001 \\
\hline Initiating Structure & .006 & .015 & .101 & .41 & .69 \\
\hline Consideration & .013 & .014 & .235 & .95 & .36 \\
\hline
\end{tabular}

Note. Level of significance (two-tailed) $=.05$ 
Table 6. Dimensions of leadership behavior and job commitment (autonomous tests)

\begin{tabular}{|c|c|c|c|c|c|}
\hline \multirow{2}{*}{ Variable } & \multicolumn{2}{|c|}{ Unstandardized coefficients } & \multirow{2}{*}{$\begin{array}{l}\text { Standardized coefficients } \\
\text { Beta }(\beta)\end{array}$} & \multirow{2}{*}{$t$} & \multirow{2}{*}{$p$-value } \\
\hline & B & Std. error & & & \\
\hline \multicolumn{6}{|c|}{ Recently Established Colleges } \\
\hline (Constant) & 3.67 & 1.60 & & 2.30 & .10 \\
\hline Initiating Structure & .076 & .028 & 1.37 & 2.69 & .07 \\
\hline Consideration & -.063 & .050 & -.639 & -1.26 & .30 \\
\hline \multicolumn{6}{|l|}{ Established Colleges } \\
\hline (Constant) & 4.23 & .770 & & 5.53 & .00 \\
\hline Initiating Structure & -.008 & .015 & -.165 & -.543 & .60 \\
\hline Consideration & .003 & .011 & .068 & .225 & .83 \\
\hline \multicolumn{6}{|l|}{ All Colleges } \\
\hline (Constant) & 3.39 & .671 & & 5.04 & .00 \\
\hline Initiating Structure & .010 & .013 & .209 & .834 & .42 \\
\hline Consideration & .003 & .012 & .056 & .225 & .82 \\
\hline
\end{tabular}

Note. Level of significance (two-tailed) $=.05$

The multivariate analysis of variance (MANOVA) was used to test the hypothesis that job satisfaction and job commitment of faculty members significantly differ with leadership behavior of deans when tested simultaneously.

The MANOVA test results using Wilk's lambda $(\Lambda)$ showed that there was no statistically significant difference in job satisfaction and job commitment based on the leadership behavior of deans in terms of "initiating structure" and "consideration" dimensions. For "initiating structure," the test outcome is as follows: $\mathrm{F}=.224, p=.88$; Wilk's $\Lambda=.961$. Similarly, for "consideration" dimension, there was no significant difference between the variables at the set $\alpha, \mathrm{F}=$ $.321, p=.81$; Wilk's $\Lambda=.940$.

When the nursing colleges are clustered according to school classification, the Wilk's $\Lambda$ values showed similar outcomes. For recently established schools, there was no statistically significant difference among the said variables in "initiating structure," ( $\mathrm{F}=3.673, p=.214$; Wilk's $\Lambda=.214)$ and "consideration" dimensions, $(\mathrm{F}=1.940, p=.34$; Wilk's $\Lambda=$ $.340)$.

Among established schools, there was no statistically significant difference among the said variables in "initiating structure," ( $\mathrm{F}=.340, p=.72$; Wilk's $\Lambda=.936)$ and "consideration" dimensions, $(\mathrm{F}=.759, p=.49$; Wilk's $\Lambda=.868)$.

Following the MANOVA results, the null hypothesis is accepted. Leadership behavior of deans does not influence job satisfaction and job commitment of faculty members when accounted for simultaneously.

The computed Wilk's $\Lambda$ determining the influence of leadership behavior of deans on job satisfaction level and job commitment level of faculty members is presented in Table 7.

Table 7. Influence of leadership behavior of deans to job satisfaction and job commitment of faculty members using multivariate analysis of variance

\begin{tabular}{lcll}
\hline Variable & Wilk's $\boldsymbol{\Lambda}$ & $\boldsymbol{F}$ & $\boldsymbol{p}$-value \\
\hline Recent Established Colleges & & \\
Constant & .141 & 6.11 & .14 \\
Initiating & .214 & 3.67 & .21 \\
Consideration & .340 & 1.94 & .34 \\
Recent Established Colleges & & \\
Constant & .265 & 13.89 & .00 \\
Initiating & .936 & .340 & .72 \\
Consideration & .868 & .759 & .49 \\
All Colleges & & & \\
Constant & 0.369 & 13.67 & .00 \\
Initiating & 0.961 & 0.328 & .72 \\
Consideration & 0.947 & 0.452 & .64 \\
\hline
\end{tabular}

Note. Level of significance $=.05$

\subsection{Relationship of School Classification to Leadership Behavior of Deans}

In this study, schools were classified as either recently established or established. Results of the independent $t$-test indicated that the self-assessment rating scores of deans of their leadership behavior, when they were clustered according to their school classification, do not have significant difference. In particular, the computed $t$-value (18) for initiating structure as leadership behavior of 0.69 ( $p$-value $=.50)$ implies that there is no significant difference in the self-assessment ratings of deans from recently established and established 
nursing colleges at the .05 significance level. Similar result was observed with regard to consideration structure as leadership behavior. The computed $t$-value (18) was 0.39 $(p$-value $=.70)$, indicating no significant difference in the self-assessment ratings of deans.

Table 8 presents the summary of computed t-values determining the significant difference in the self-assessment ratings of deans of the leadership behavior with school classification.

Table 8. Relationship of school classification and leadership behavior of deans based on self-assessment only

\begin{tabular}{llll}
\hline Dimension of Leadership Behavior & $\boldsymbol{t}$-value & $\mathbf{d f}$ & $\boldsymbol{p}$-value \\
\hline Initiating Structure & .69 & 18 & .50 \\
Consideration & .39 & 18 & .70 \\
\hline
\end{tabular}

Note. Level of significance (two-tailed) $=.05 t$-value. Test statistic. df. Degrees of freedom.

As shown in Table 9, computed $t$-values determined the significant difference in the faculty ratings of the leadership behavior of their deans when school classification is utilized as independent variable. Results showed that the faculty assessment rating scores of the leadership behavior of their respective dean do not significantly differ when they were clustered according to their school classification. Specifically, the computed $t$-value (18) for initiating structure as leadership behavior was $.050(p$-value $=.961)$ which indicated that the difference in the assessment rating scores of faculty members from recently established and established nursing colleges was not significant at the 0.05 significance level. In the same manner, the rating scores for consideration dimension do not significantly differ, considering the computed $t$-value $(18)$ of $1.29(p$-value $=.214)$. Conclusively, the null hypothesis is accepted.

Table 9. Relationship of school classification and leadership behavior of deans based on faculty rating only

\begin{tabular}{lccc}
\hline Dimension of Leadership Behavior & $\boldsymbol{t}$-value & df & $\boldsymbol{p}$-value \\
\hline Initiating Structure & .050 & 18 & .96 \\
Consideration & 1.29 & 18 & .21 \\
\hline
\end{tabular}

Note. Level of significance (two-tailed) $=.05 . t$-value. Test statistic. df. Degrees of freedom.

The summary of computed $t$-values determining the significant difference in the self-assessment rating scores of deans and faculty rating scores of the leadership behavior of deans in terms of initiating structure and consideration dimension when school classification is considered as test factor is presented in Table 10.

Results of the $t$-tests indicated that the self-assessment ratings of deans and the scores of faculty members on the leadership behavior of deans do not significantly differ. Taking all sample schools, with initiating structure as test variable, the computed $t$-value (19) was $1.69(p$-value $=.11)$, which suggests that the self-assessment ratings of deans and the rating scores of faculty members pertaining to initiating structure do not significantly differ. Similar result was observed with regard to consideration dimension. The computed $t$ value (19) was .264 ( $p$-value $=.80)$, implying that the rating scores of deans and faculty members do not have significant difference. Thus, the null hypothesis is accepted.

Table 10. Relationship of school classification and leadership behavior of deans based on self-assessment and faculty rating

\begin{tabular}{llll}
\hline Dimension of Leadership Behavior & $\boldsymbol{t}$-value & $\mathbf{d f}$ & $\boldsymbol{p}$-value \\
\hline Recently established schools & & & \\
Initiating Structure & -.48 & 5 & .65 \\
Consideration & -.10 & 5 & .92 \\
Established schools & & & \\
Initiating Structure & -1.65 & 13 & .12 \\
Consideration & .33 & 13 & .74 \\
All sample schools & & & \\
Initiating Structure & 1.69 & 19 & .11 \\
Consideration & .264 & 19 & .80 \\
\hline
\end{tabular}

Note. Level of significance (two-tailed) $=.05$; $t$-value. Test statistic.df. Degrees of freedom.

\subsection{Relationship of school classification to job satisfac- tion and job commitment}

The $t$-test for independent samples indicated that job satisfaction levels of faculty members from recently established and established nursing colleges in Metro Manila do not significantly differ. In particular, the computed $t$-value (18) of .294 ( $p$-value $=.772)$ implies that job satisfaction levels of faculty members were not significantly different, despite recently established nursing schools $(\mathrm{M}=4.20, \mathrm{SD}=.25)$ attaining higher scores than established nursing schools $(M=4.16$, $\mathrm{SD}=.31)$. Thus, the null hypothesis is accepted.

The $t$-test for independent samples indicated that job commitment levels of faculty members from recently established and established nursing colleges in Metro Manila do not significantly differ. In particular, the computed $t$-value (18) of .294 ( $p$-value $=.77)$ implies that job satisfaction levels of faculty members were not significantly different, despite established nursing schools $(\mathrm{M}=3.97, \mathrm{SD}=.30)$ attaining higher scores than recently established nursing schools $(\mathrm{M}=$ $4.01, \mathrm{SD}=.21)$.

\section{Discussion}

\subsection{Descriptive analysis}

The leadership behavior of nursing college deans were perceived at considerably high levels by deans themselves and 
their faculty members. Initiating structure dimension was highly exhibited by the deans of selected nursing colleges in NCR. Among the deans and faculty members of nursing colleges, the deans were generally considered as "highly initiating." This result, however, may not be surprising considering that deans are heads of colleges. The findings also showed that there was a congruence in the two dimensions of leader behavior based on the self-evaluation by the dean and the evaluation made by the faculty as evidenced by the close mean leadership behavior scores.

On the whole, "initiating structure" as a leadership behavior of deans of nursing colleges was observed by faculty members to be high. Comparing the self-rating results of deans and the assessment ratings of faculty members, the latter ratings were generally higher than the self-assessment ratings of the dean. Nonetheless, the results implied that the deans were assertive in administering their college by carrying out policies. In addition, they also provided proper direction and guidance of faculty members in achieving the goals of the school as well as theirs.

The deans and faculty members of nursing colleges were also generally perceived as "very highly considerate." Such result may be expected considering that deans of nursing colleges are themselves nurses by profession. As such, they apply certain qualities of a nurse which include in administering their respective college which, among others, include being considerate, caring, and understanding in leading and dealing with their faculty members and staff. As explained by Everard, Morris, and Wilson ${ }^{[30]}$ deans, as managers, become one of the most important influences on the working lives of the faculty and staff who report directly or indirectly to them. As heads of their college, their value system will fashion to a large extent their faculty and staff to become happy or unhappy in their work; their work priority; and the standard which they observe and reflect.

Abelardo ${ }^{[31]}$ pointed out that the managerial communication competence of the school managers as assessed by themselves were verbally described as "highly evident" while their teachers' assessment was "very evident." This explained that the assessment of the school managers as regards their transformational leadership was higher than those of the teachers.

Results suggested that faculty members of nursing colleges are generally "satisfied" with their job. Deans of nursing colleges should not be complacent, however, for these do not exclude the possibility that there are faculty members that may be unhappy or dissatisfied with some aspects of their jobs. As indicated by the mean ratings of faculty members there are areas that need to be improved, specifically, the way school policies are put into practice. Health education cannot create positive changes in nursing schools without paying attention to the needs and conditions of nurse educators. ${ }^{[32]}$

For an organizational point of view, job satisfaction is an important component because it leads to higher organizational commitment of employees. High commitment leads to overall organizational success and development. ${ }^{[33]}$ Moreover, there is an observed growth, increased effectiveness and efficiency of the organization, and low employee turnover. ${ }^{[34]}$

Mosadeghard ${ }^{[34]}$ further explained that job satisfaction dimensions like nature of the job, management and supervision, task requirement, co-workers, job security, and recognition and promotion had more effect on employees' organizational commitment in an organizational set-up.

Job satisfaction is usually perceived as a factor of organizational outcomes, and strong relationships between job satisfaction and organizational performance, turnover, organizational commitment and organizational trust were observed. ${ }^{[35]}$

Faculty members were also perceived to be "committed" to their teaching job. This finding is similar in both recently established and established nursing colleges. Being loyal to teaching job is the most frequent indication of this commitment. However, since some faculty members develop a feeling like staying at home than going to school, colleges must create working environments that encourage and stimulate productivity and camaraderie. Job commitment of workers is one of the major factors necessary in achieving the goals of an organization.

\subsection{Relationships among study variables}

Pearson correlation results supported the notion that initiating structure is strongly associated with job commitment among recently established schools of nursing. The study findings resonated results of earlier studies. Job satisfaction and organizational commitment tend to increase as the staff nurses perceive that their manager manifests authentic leadership. However, the intensity of this association was diminished by nurse tenure and were no longer significant for nurses with more than 20 years of tenure, which is due in part to the increased experience and critical decision-making of the staff. To increase job satisfaction and organizational commitment among nurses, different approaches should be considered based on nurse tenure. ${ }^{[36]}$

Worthy et al. ${ }^{[36]}$ examined leadership styles of nursing deans at public U.S. universities and observed that the faculty perceived that nursing deans displayed transformational leadership style more frequently. Nursing faculty were relatively satisfied in their jobs. Moreover, nursing deans who practiced 
attributed idealized influence received higher satisfaction scores. Leadership that is built on leader-member trust and informal manner of communication increases the meaningfulness of job interpretation. Additionally, transformational leadership significantly predicts job satisfaction. It was also found that job satisfaction had a significant influence on employee performance. ${ }^{[37]}$ In contrary, in a study on job satisfaction and nurse educators' understanding of leadership style in Taiwan, faculty members attain higher job satisfaction if they are headed using a transactional rather than a transformational leadership style. ${ }^{[38]}$ On the other hand, Byrne and Martin ${ }^{[39]}$ supported the idea that professional satisfaction and organizational commitment of nursing faculty members were not significantly influenced by whether they perceive their leader as either a transformational or a transactional type. In Thailand, Intaraprasong and team ${ }^{[40]}$ found that situational leadership styles do not have significant correlations with job satisfaction and organizational commitment of head nurses.

Top et al. ${ }^{[41]}$ explained that one transformational leadership dimension (articulating a vision), two job satisfaction dimensions (pay and supervision) and two organizational commitment dimensions (affective commitment and normative commitment) significantly predict organizational trust. Moreover, transformational leadership behavior enables the leaders to embrace strong emotional ties to their followers.

In a study of Dahinten et al., ${ }^{[42]}$ the relationships between structural empowerment, psychological empowerment and job satisfaction among staff nurses were investigated. Structural empowerment was the strongest independent predictor of job satisfaction, followed by leader empowering behaviors and psychological empowerment. These relationships among variables were consistent with results from previous findings in different countries. ${ }^{[43-46]}$

In Florida, USA, Derby-Davis ${ }^{[47]}$ studied the influence of motivational and hygiene factors in Herzberg's theory on job satisfaction and turnover intention in nurse educators. The results reflect that managers' consideration for the job satisfaction of employees bolster the sense of responsibility in the faculty members and ultimately decreases intent to leave. Saleem ${ }^{[48]}$ asserted that organizational politics is mainly affected by leadership, which in turn, influence the job satisfaction of employees. Elshout et al. ${ }^{[49]}$ argued that organizational success is dependent on various factors. Yet, the major variables to organization effectiveness are leadership style and job satisfaction.

Several studies focused on the influence of empowerment to job satisfaction. Owen et al. ${ }^{[50]}$ argued that faculty job satisfaction was related to overall psychological empowerment and total structural empowerment. Psychological empowerment as a correlate of job satisfaction was also corroborated by Chung and Kowalski. ${ }^{[51]}$ Among associate degree nurse (ADN) educators, job satisfaction and psychological empowerment showed significant relationship. Two components of structural empowerment, Resources and Formal Power, demonstrated moderate positive correlations with job satisfaction. ${ }^{[52]}$

One implication of improving job satisfaction and commitment was to retain the faculty members' intent to remain employed. Burnout and low job satisfaction are major causes of nurses leaving their current jobs. Improving the work environment of nurses may decrease the magnitude of job burnout and of job dissatisfaction and, therefore, increase the intention of nursing staff to retain employment. Nurses in work environments considered to be "favorable" would more likely achieve improved job satisfaction and reduced turnover intention than their colleagues in self-reported "poor" work environments. ${ }^{[53]}$

In various earlier studies, job satisfaction was noted to be a key determinant in faculty retention. ${ }^{[47,51,54,55]}$ However, Wang \& Liesveld ${ }^{[56]}$ asserted that satisfaction with institutional support for teaching improvement was only minimally significant. This finding may be related to faculty-related concerns which may be addressed if the administrators would provide more supportive institutional policies, professional development opportunities, and more research grants. Faculty management may be a significant responsibility for the college administrator with the aim of slowing down employee attrition and deterring intellectual drain resulting from leaving of employees. ${ }^{[57]}$ The most important variable associated with employee retention was professional satisfaction with faculty identity, especially the ability to influence nursing practice. ${ }^{58]}$

Moreover, the study by Tourangeau and team (2014) ${ }^{[59]}$ suggested that the intent to remain employed of nurse faculty for the succeeding five years was positively correlated with quality of relationships with colleagues, being employed full-time, having dependents, satisfaction with balancing work and life, quality of education, satisfaction with current job status, and satisfaction with access to required human resources, e.g., teaching assistants and support staff.

Various factors, especially job satisfaction, were explained to influence commitment of employees to their job and company. According to a study of Sikorska-Simmons ${ }^{[60]}$ in USA, organizational commitment was positively correlated with job satisfaction. Satisfied and committed health workers, including those who do not deal directly with patients, boost an organization's reputation for quality care, which is a strong 
indication of organizational commitment. ${ }^{[61]}$ Positive correlations were found among job satisfaction, work environment, and organizational commitment. There is $63 \%$ variance in nurses' organizational commitment influenced by the study variables. Self-realization, nurses' participation in management and representative power, nurse managers' attitudes and leadership qualities, general quality, and communication among physicians, nurses and colleagues were significant predictors. ${ }^{[62]}$ Findings of Byrne and Martin ${ }^{[57]}$ suggested that professional satisfaction influences organizational commitment and vice versa. Knowing this, formal leadership training and preparation is necessary to lead nursing education through unstable times.

The study by Ahmed et al. ${ }^{[63]}$ revealed that intrinsic motivational factors are significantly correlated with employee job satisfaction. Meanwhile, hygiene (extrinsic) factors do not have relationship with employee job satisfaction. Group cohesion, job satisfaction, and structural empowerment had a significant effect on organizational commitment. Organizational commitment had a significant effect on turnover intent. ${ }^{[64]}$ Top et al. ${ }^{[65]}$ explained that organizational trust and two job satisfaction dimensions (contingent rewards and communication) were significant predictors for organizational commitment. However, this is not congruent with the results of the study wherein job satisfaction and job commitment showed no significant correlation.

Considering that the study variables were mostly not correlated, other variables that may influence job satisfaction and commitment must be explored. In Iran, Foroughi et al. ${ }^{[66]}$ found that job satisfaction is highest at nature of the job and lowest in terms of welfare opportunities given to staff. Factors such as salary, welfare opportunities, and career progress may increase the job satisfaction of nurses.

Jones ${ }^{[67]}$ investigated the relationships among education, teacher self-efficacy, and career satisfaction of nurse faculty to career commitment. Teacher self-efficacy was positively directly and indirectly related to career commitment among the nurse faculty. These results were congruent with previous studies wherein career satisfaction and career commitment were also noted to have a direct positive relationship. ${ }^{[68,69]}$

Job satisfaction confirmed statistically significant positive relationships with personal and family policies, collaboration, tenure clarity, institutional leadership, shared governance, and departmental engagement. ${ }^{[70]}$ Similarly, institutional leadership was found to be a determining factor for job satisfaction and intent to stay in previous studies. ${ }^{[47,71,72]}$ This suggests that meticulous selection of institutional managers and developments of administrative support mechanisms.
The relationship between number of years of experience and job satisfaction was found to be significant. ${ }^{[73]}$ As experience increases, the level of satisfaction recorded also increases. Experience is one of the best predictors of job satisfaction ${ }^{[74]}$ and staff retention. ${ }^{[75]}$

\subsection{Implications to nursing school management}

The results of the study provided practical implications for effective management of nursing schools which deans could possibly utilize in the administration and supervision of their respective schools.

Deans of nursing colleges are leaders in their own right. Deans should, therefore, be visionaries and initiators of programs and activities that can drive their school towards achieving quality education, on one hand, and considerate on faculty members by motivating in achieving high work performance.

Job satisfaction and job commitment of faculty members do not solely depend on the leadership behavior of deans. For as long as the factors intrinsic to them are considered important, present in the school environment, and obtainable, their high levels of job satisfaction and job commitment will be maintained.

Deans have the responsibility of steering the school towards achieving its goals and objectives. However, this cannot be achieved unless faculty members are satisfied and committed to their jobs. It is therefore necessary the deans should always keep a perceptive attitude about the satisfaction and commitment levels of faculty members so that they are wellinformed of the factors that generate high satisfaction and commitment and which ones curtail them.

The administration of a nursing college does not only involve managing of faculty members and students. It is a task directed towards a lot of concerns. Deans should discharge their duties like puzzle solvers who piece together all areas of the school by instituting and implementing policies, programs, and activities that are geared towards achieving the goals and objectives of the entire organization.

\subsection{Limitations}

The results of this study were subject to some limitations. The samples of study were only delimited to the selected colleges of nursing in the National Capital Region (NCR), Philippines. This means that the findings could not be applied to nursing colleges outside NCR or to other schools of different academic programs. Thus, generalizability of the study findings must be investigated in future research with a more expansive and diverse samples. The generalizability of the study results was limited due to the use of self-reports 
and cross-sectional data as data gathering methods. Determining the leadership behavior of deans of other colleges, e.g., Business Administration, Arts and Sciences, Engineering, Education, can provide a more comprehensive picture of school administrators. In addition, a deeper understanding of the job satisfaction and commitment levels of faculty members will provide school administrators a guide in leading their organization towards attainment of school goals and objectives. Moreover, this study was correlational by design, so no causal inferences could be made.

\section{Conclusions}

Deans of nursing college manifested both initiating structure and consideration dimensions relative to leadership behaviors although being considerate was more prominent than initiating. The perceptions of deans regarding their leadership behavior in terms of "initiating structure" and "consideration dimension" are congruent with the observation of faculty members of how they behave as leaders. The satisfaction level of faculty members indicated their desire to provide nursing students with quality education. Faculty members of nursing colleges were generally committed to their job as teachers by exuding the goals and objectives of the college/university in providing quality nursing education to students.

Leadership behaviors of deans of recently established nursing colleges did not significantly differ with leadership behavior of deans of established nursing colleges. The job satisfaction level of faculty members did not significantly differ; thus school classification is not an essential condition in generating high job satisfaction among faculty members. The commitment levels of faculty members did not significantly vary; therefore the classification of school is not a critical element in producing high commitment of faculty members.

Among recently established nursing schools, the more the deans manifested initiation structure leader behavior, the higher the job commitment of faculty members. Among established schools, leadership behavior of deans in terms of "initiating structure" and "consideration" dimension did not determine the level of job satisfaction and job commitment of faculty members. This suggested that there are more crucial factors other than leadership behavior that bring about high satisfaction and commitment to teaching job among faculty members.

\section{CONFLicts OF InTEREST Disclosure}

The author declares that there is no conflict of interest.

\section{REFERENCES}

[1] Sebastian JG, Mosley CW, Bleich MR. The academic nursing practice dean: an emerging role. J Nurs Educ. $2004 \mathrm{Feb}$; 43(2): 66-70 PMid:14974512 https://doi.org/10.3928/01484834-20040 201-02

[2] Center for Higher Education (CHED) Memorandum Order No. 5 (2008).

[3] Center for Higher Education (CHED) Memorandum Order No. 14 (2009).

[4] Rosales A, Arugay Y, Divinagracia C, et al. Analytical Study on the Nurses Licensure Examination Performance of Graduates of Philippine Colleges of Nursing. PJN. 2014; 84(1): 4-23.

[5] Murphy JF, Goldring E, Cravens X, et al. The Vanderbilt Assessment of Leadership in Education: Measuring Learning-Centered Leadership. East China Normal University Journal. 2007 Aug.

[6] Hughes R, Ginnett R, Curpy G. Leadership: Enhancing the Lesons of Experience (5th ed.). USA: McGraw-Hill/Irwin Inc. 2006.

[7] Lim G, Daft RL. The Leadership Experience in Asia. Singapore: Thompson Learning. 2004.

[8] Halpin AW. Theory and research in administration. Macmillan. 1966.

[9] Alejandro NT. Leadership Style, Organizational Climate and Teachers' Participation in Decision-Making. Mariano Marcos State University. 1992 Mar.

[10] Singh J. Use of leadership practices by the managers and their impact on the job satisfaction of employees in the hotel industry. University of Nevada, Las Vegas. ProQuest Dissertations Publishing. 1998.
[11] Singh A, Pestonjee, D. Supervisory Behaviour and Job Satisfaction. Indian Journal of Industrial Relations. 1974; 9(3): 407-416.

[12] Spector PE. Measurement of human service staff satisfaction: Development of the Job Satisfaction Survey. Am J Commun Psychol 1985; 13: 693-713. PMid:4083275 https://doi.org/10.1007/ BF00929796

[13] Robbins SP. Organizational Behavior: Concepts, Controversies, Applications. 8th ed. USA: Prentice Hall International, Inc; 1998.

[14] Blake R, Mouton J. The Managerial Grid: The Key to Leadership Excellence. Houston: Gulf Publishing Co.; 1964.

[15] Hersey P, Blanchard KH. Management of Organizational Behavior 3er Edition-Utilizing Human Resources. Prentice Hall, New Jersey; 1977.

[16] Leary PA. The Relationship of Leadership Styles of Selected West Virginia Deans and Department Chairs to Job Satisfaction of Departmental Faculty Members. National Forum Journals. 1995.

[17] Bright D, Richards M. The Academic Deanship: Individual Careers and Institutional Roles. San Francisco, CA: Jossey-Bass; 2001

[18] Bloom B. Taxonomy of educational objectives: The classification of educational goals - Handbook 1, Cognitive Domain. New York: David McKay; 1956

[19] Baek H, Han K, Ryu E. Authentic leadership, job satisfaction and organizational commitment: The moderating effect of nurse tenure. Journal of Nursing Management. 2019; 27(8): 1655-1663. PMid:31454125 https://doi.org/10.1111/jonm. 12853

[20] Herzberg F, Mausner B, Snyderman BB. The Motivation to Work (2nd ed.). New York: John Wiley; 1959. 
[21] Bektas C. Explanation of intrinsic and extrinsic job satisfaction via mirror model. Business \& Management Studies: An International Journal. 2017; 5(3): 627-639. https ://doi .org/10.15295/bmi j.v5i3.118

[22] Ćulibrk J, Delić M, Mitrović S, et al. Job Satisfaction, Organizational Commitment and Job Involvement: The Mediating Role of Job Involvement. Front. Psychol. 2018; 9: 132. PMid:29503623 https://doi.org/10.3389/fpsyg.2018.00132

[23] Benton DA. Applied Human Relations An Organizational and Skill Development. 6th ed. New Jersey: Prentice-Hall; 1998.

[24] Fleishman EA. A leader behavior description for industry. In Stogdill RM, Coons AE (Eds.), Leader Behavior: Its Description and Measurement, Columbus: The Ohio State University, Bureau of Business Research, Monograph No. 88; 1957.

[25] Likert R. Motivational Dimensions of Administration. Stanford: Stanford University, Institute on Manpower Utilization and Government Personnel; 1951.

[26] Polit DF, Beck CT. Essentials of Nursing Research: Appraising Evidence for Nursing Practice. 7th ed. Philadelphia: Lippincott Williams \& Wilkins; 2010.

[27] Halpin AW, Winer BJ. A factorial study of the Leader Behavior Descriptions. In Stogdill RM, Coons AE (Eds.), Leader behavior: Its description and measurement. Columbus: The Ohio State University, Bureau of Business Research, Monograph No. 88; 1957.

[28] Weiss DJ, Dawis RV, England GW, et al. Manual for the Minnesota Satisfaction Questionnaire. Minneapolis: University of Minnesota, Industrial Relations Center; 1967.

[29] Cohen J. Statistical power analysis for the behavioral sciences (2nd ed.). Hillside, NJ: Lawrence Erlbaum Associates; 1988.

[30] Everard B, Morris G, Wilson I. Effective School Management. 4th Edition. USA. Paul Chapman Educational Publishing; 2004.

[31] Abelardo J. Transformational Leadership Behavior, Managerial Communication Competence and Decision Making Practices of Elementary School Managers. Dr. Gloria Lacson Foundation College Inc, Nueva Ecija; 2001.

[32] Arian M, Soleimani M, Oghazian MB. Job satisfaction and the factors affecting satisfaction in nurse educators: A systematic review. Journal of professional nursing: official journal of the American Association of Colleges of Nursing. 2018; 34(5): 389-399. PMid:30243696 https://doi.org/10.1016/j.profnurs.2018.07.004

[33] Feinstein AH. A study of relationships between job satisfaction and organizational commitment among restaurant employees; 2000.

[34] Mosadeghard AM. A study of the relationship between job satisfaction, organizational commitment and turnover intention among hospital employees. Health Services Management Research. 2008; 21: 211-217. PMid:18957399 https://doi.org/10.1258/hsmr .2007 .007015

[35] Liao S, Hu D, Chung H. The relationship between leader-member relations, job satisfaction and organizational commitment in international tourist hotels in Taiwan. Int J Hum Resource Manag. 2009; 20(8): 1810-1826. https://doi.org/10.1080/095851909030 87222

[36] Worthy K, Dawson RM, Tavakoli AS. Relationships Among Nursing Deans' Leadership Styles and Faculty Job Satisfaction Levels. The Journal of nursing education. 2020; 59(2): 68-75. PMid:32003845 https://doi.org/10.3928/01484834-20200122-03

[37] Biswas S. Impact of Psychological Climate \& Transformational Leadership on Employee Performance. Indian Journal of Industrial Relations. 2012; 48(1): 105-119.

[38] Chen HC, Beck SL, Amos LK. Leadership styles and nursing faculty job satisfaction in Taiwan. Journal of Nursing Scholarship. 2005;
37(4): 374-380. PMid:16396412 https://doi.org/10.1111/j . 1547-5069.2005.00064.x

[39] Byrne DM, Martin BN. A solution to the shortage of nursing faculty: awareness and understanding of the leadership style of the nursing department head. Nurse educator. 2014; 39(3): 107-112. PMid:24743172 https://doi.org/10.1097/NNE.0000000000 000031

[40] Intaraprasong B, Potjanasitt S, Pattaraarchachai J, et al. Situational leadership styles, staff nurse job characteristics related to job satisfaction and organizational commitment of head nurses working in hospitals under the jurisdiction of the Royal Thai Army. Journal of the Medical Association of Thailand=Chotmaihet thangphaet. 2012; 95(6): 109-S119.

[41] Top M, Tarcan M, Tekingündüz S, et al. An analysis of relationships among transformational leadership, job satisfaction, organizational commitment and organizational trust in two Turkish hospitals. The International Journal of Health Planning and Management. 2013; 28(3): 217-241. PMid:23239046 https://doi .org/10.1002/hp m. 2154

[42] Dahinten VS, Lee SE, MacPhee M. Disentangling the relationships between staff nurses' workplace empowerment and job satisfaction. Journal of Nursing Management. 2016; 24(8): 1060-1070. PMid:27353065 https://doi .org/10.1111/jonm. 12407

[43] Cai CF, Zhou ZK, Yeh H. Empowerment and its effects on clinical nurses in central China. International Nursing Review. 2011; 58(1): 138-144. PMid:21281306 https://doi.org/10.1111/j. 1466-7657.2010.00848.x

[44] Ouyang YQ, Zhou WB, Qu H. The impact of psychological empowerment and organisational commitment on Chinese nurses' job satisfaction. Contemporary Nurse. 2015; 50(1): 80-91. PMid:26060889 https://doi.org/10.1080/10376178.2015.1010253

[45] Lautizi M, Laschinger HK, Ravazzolo S. Workplace empowerment, job satisfaction and job stress among Italian mental health nurses: an exploratory study. Journal of Nursing Management. 2009; 17(4): 446452. PMid:19531144 https://doi.org/10.1111/j.1365-283 4.2009.00984.x

[46] Ahmad N, Oranye NO. Empowerment, job satisfaction and organisational commitment: a comparative analysis of nurses working in Malaysia and England. Journal of Nursing Management. 2010; 18 (5): 582-591. PMid:20636507 https://doi.org/10.1111/j.13 $65-2834.2010 .01093 . x$

[47] Derby-Davis MJ. Predictors of Nursing Faculty's Job Satisfaction and Intent to Stay in Academe. Journal of Professional Nursing. 2014; 30(1): 19-25. PMid:24503311 https://doi.org/10.1016/j.pr ofnurs.2013.04.001

[48] Saleem H. The impact of leadership styles on job satisfaction and mediating role of perceived organizational politics. Procedia - Social and Behavioral Sciences. 2015; 172: 563-569. https: //doi.org/10.1016/j.sbspro.2015.01.403

[49] Elshout R, Scherp E, Van Der Feltz-Cornelis C. Understanding the link between leadership style, employee satisfaction, and absenteeism: a mixed methods design study in a mental health care institution. Neuropsychiatric Disease and Treatment. 2013; 9: 823-837. PMid:23818784 https://doi.org/10.2147/NDT.S43755

[50] Owen DC, Boswell C, Opton L, et al. Engagement, empowerment, and job satisfaction before implementing an academic model of shared governance. Applied Nursing Research. 2018; 41: 29-35. PMid:29853210 https://doi.org/10.1016/j . apnr.2018.02 .001

[51] Chung CE, Kowalski S. Job stress, mentoring, psychological empowerment, and job satisfaction among nursing faculty. Journal of 
Nursing Education. 2012; 51: 381-388. PMid:22588567 https: //doi.org/10.3928/01484834-20120509-03

[52] Baker SL, Fitzpatrick JJ, Griffin MQ. Empowerment and job satisfaction in associate degree nurse educators. Nursing education perspectives. 2011; 32(4): 234-239. PMid:21923003 https ://doi org/10.5480/1536-5026-32.4.234

[53] Chen YM, Fang JB. Correlation Between Nursing Work Environment and Nurse Burnout, Job Satisfaction, and Turnover Intention in the Western Region of Mainland China. The Journal of Nursing. 2016; 63(1): 87-98. https://doi.org/10.6224/JN.63.1.87

[54] Al-Hussami M, Saleh MY, Abdalkader RH, et al. Predictors of nursing faculty member's organizational commitment in governmental universities. Journal of Nursing Management. 2011; 19: 556-566 PMid:21569152 https://doi .org/10.1111/j.1365-2834. 20 10.01148.x

[55] Baker S. Nurse educator orientation: Professional development that promotes retention. The Journal of Continuing Education in Nursing. 2010; 41: 413-417. PMid:20506931 https://doi.org/10.3928/ 00220124-20100503-02

[56] Wang Y, Liesveld J. Exploring Job Satisfaction of Nursing Faculty: Theoretical Approaches. Journal of professional nursing: official journal of the American Association of Colleges of Nursing. 2015; 31(6): 482-492. PMid:26653042 https://doi.org/10.1016/j . profnurs.2015.04.010

[57] Byrne DM, Martin BN. A solution to the shortage of nursing faculty: awareness and understanding of the leadership style of the nursing department head. Nurse educator. 2014; 39(3): 107-112. PMid:24743172 https://doi.org/10.1097/NNE. 0000000000 000031

[58] Berent GR, Anderko L. Solving the nurse faculty shortage: exploring retention issues. Nurse educator. 2011; 36(5): 203-207. PMid:21857339 https://doi.org/10.1097/NNE.0b013e3182 $297 \mathrm{c} 4 \mathrm{a}$

[59] Tourangeau A, Saari M, Patterson E, et al. Work, work environments and other factors influencing nurse faculty intention to remain employed: a cross-sectional study. Nurse Education Today. 2014; 34(6): 940-947. PMid:24238852 https://doi.org/10.1016/j. nedt.2013.10.010

[60] Sikorska-Simmons E. Predictors of organizational commitment among staff in assisted living. Gerontologist. 2005; 45(2): 196-205. PMid:15799984 https://doi.org/10.1093/geront/45.2.19 6

[61] Meyer JP, David J, Stanley LH, et al. Affective, continuance and normative commitment to the organization: a meta-analysis of antecedents, correlates, and consequences. J Vocat Behav. 2002; 61(1): 20-52. https://doi.org/10.1006/jvbe. 2001.1842

[62] Seren-Intepeler S, Esrefgil G, Yilmazmis F, et al. Role of job satisfaction and work environment on the organizational commitment of nurses: a cross-sectional study. Contemporary nurse. 2019; 55(45): 380-390. PMid:31558109 https://doi .org/10.1080/1037 6178.2019 .1673668
[63] Ahmed I, Nawaz M, Iqbal N, et al. International Journal of Business Management. 2010; 70-80.

[64] Church CD, He Z, Yarbrough S. Factors Influencing Organizational Commitment and Turnover in Nurse Residents. Journal of Continuing Education in Nursing. 2018; 49(10): 482-488. PMid:30257032 https://doi .org/10.3928/00220124-20180918-09

[65] Top M, Tarcan M, Tekingündüz S, et al. An analysis of relationships among transformational leadership, job satisfaction, organizational commitment and organizational trust in two Turkish hospitals. The International Journal of Health Planning and Management. 2013; 28(3): 217-241. PMid:23239046 https : //doi .org/10.1002/hp $\mathrm{m} .2154$

[66] Foroughi F, Kharrazi H, Iranfar S, et al. Job Satisfaction and its Affecting Factors from the Viewpoints of Faculty Members of Kermanshah University of Medical Sciences. Iranian Journal of Medical Education. 2008; 7(2): 335-342

[67] Jones M. Career Commitment of Nurse Faculty. Research and theory for nursing practice. 2017; 31(4): 364-378. PMid:29137695 https://doi.org/10.1891/1541-6577.31.4.364

[68] Fu JR. Understanding career commitment of IT professionals: Perspectives of pushpull-mooring framework and investment model. International Journal of Information Management. 2011; 31(3): 279293. https://doi.org/10.1016/j.ijinfomgt. 2010.08.008

[69] Niu HJ. Investigating the effects of teacher self-efficacy on foodservice industry employees' career commitment. International Journal of Hospitality Management. 2010; 29(4): 743-750. https: //doi.org/10.1016/j.ijhm.2010.03.006

[70] Lee P, Miller MT, Kippenbrock TA, et al. College nursing faculty job satisfaction and retention: A national perspective. Journal of Professional Nursing: Official Journal of the American Association of Colleges of Nursing. 2017; 33(4): 261-266. PMid:28734484 https://doi.org/10.1016/j.profnurs.2017.01.001

[71] Kaufman K. The national league for nursing annual survey of schools nursing data review. 2007.

[72] O'Meara KA, Lounder A, Campbell CM. To heaven or hell: Sensemaking about why faculty leave. Journal of Higher Education. 2014; 85(5): 603-632. https://doi.org/10.1080/00221546. 2014. 11777342

[73] Al-Maqbali F. The impact of the leadership styles of Deans on the Faculty members' level of job satisfaction in nursing education in Oman [dissertation]. [Glasgow]: University of Glasgow; 2017.

[74] Seraj B, Ghadimi S, Mirzaee M, et al. Job satisfaction and its influential factors in dental academic members in Tehran, Iran. Annals of medical and health sciences research. 2014; 4(2): 192-7. PMid:24761236 https://doi .org/10.4103/2141-9248.1290 35

[75] Li J, Lambert VA. Job satisfaction among intensive care nurses from the People's Republic of China. International Nursing Review. 2008; 55(1): 34-9. PMid:18275533 https://doi.org/10.1111/j.14 $66-7657.2007 .00573 . x$ 